\title{
Metonymy in Spanish and American parliamentary speeches: Obama's State of the Union Address versus Rajoy's State of the Nation Address
}

\section{La metonimia en los discursos parlamentarios españoles y estadounidenses: El discurso del estado de la unión de Obama frente al discurso del estado de la nación de Rajoy}

ABSTRACT: The present study compares metonymy use in a Spanish political speech with an American political speech, which belong to two different debate traditions, to convince the public of economic victory after the worldwide financial crisis. For that purpose, we analyze the metonymies employed in the Economy sections of the 2015 State of the Union Address in the US and in the 2015 State of the Nation Address in Spain. The present study aims at answering the following research questions:

1. What metonymies do President Obama and Prime Minister Rajoy use in their American and Spanish political speeches in an attempt to convince the public of economic victory?

2. What are the similarities and differences between the role of metonymy in shaping public opinion about economic recovery in America and Spain in both speeches?

To answer these questions, we use the Conceptual Metonymy Theory (Dirven \& Ruiz de Mendoza Ibáñez 2010), which stems from the general framework of Conceptual Metaphor Theory (Lakoff \& Johnson 1980/2003). The results indicate that the politicians use metonymies to sway the audience's opinion to their side and, thus, used them ideologically. The politicians differ however in the stress given to different aspects of the economic recovery.

Keywords: metonymy, political speech, persuasion, ideology, Critical Discourse Analysis and Conceptual Metonymy Theory. 
RESUMEN: Este estudio presenta un análisis comparativo del uso de la metonimia en dos discursos políticos pertenecientes a dos tradiciones de discursos distintas -el debate político americano y el español- con la intención de convencer a la audiencia de la recuperación económica tras la crisis financiera mundial. Para ello, analizamos las metonimias empleadas en las secciones de economía del Debate para el Estado de la Unión del año 2015 en EE.UU. y el Debate para el Estado de la Nación del mismo año en España. Este trabajo pretender dar respuesta a las siguientes preguntas:

1. ¿Qué metonimias utilizan el presidente Obama y el presidente del gobierno Rajoy en los debates políticos para convencer a la audiencia del éxito económico de EE.UU. y España?

2. ¿Cuáles son las similitudes y diferencias entre el papel dado a la metonimia para formar la opinión del público sobre la recuperación económica en EE.UU. y en España en los dos discursos?

Para contestar estas preguntas usamos la teoría de la metonimia conceptual (Dirven y Ruiz de Mendoza Ibáñez, 2010), que parte del marco general de la teoría de la metáfora conceptual (Lakoff y Johnson 1980/2003). Los resultados indican que los políticos utilizan las metonimias para cambiar la opinión de la audiencia en su favor y, por tanto, se utilizan con propósitos ideológicos. Los políticos se diferencian sin embargo en el acento dado a diferentes aspectos de la recuperación económica.

Palabras clave: metonimia, discurso político, persuasión, ideología, análisis del discurso y teoría de la metonimia conceptual.

\section{INTRODUCTION}

It is now widely accepted that politicians attempt to persuade their audience and influence their behavior to a position that is favorable to them. However, it is less clear what devices they use to achieve their purpose. Various studies (Meadows, 2007; Cortés de los Ríos, 2010; Cabrejas-Peñuelas and Díez-Prados; 2014, Cabrejas-Peñuelas, 2015) have uncovered diverse linguistic tools (i.e. rhetorical figures, evaluative language, lexical choice, among others) that serve politicians «to trigger powerful connections in the minds of listeners» (Meadows $2007,14)$ and, thus, it is no wonder that they exploit their rhetorical power to achieve their own political ends. One of such tools is metonymy, which is artfully manipulated to attract the audience's attention and, ultimately, to persuade them.

Parliamentary debates are considered as «campo[s] de batalla» [battlefields] (Martín Rojo 2000: 112), which take confrontation as their keystone (2000: 
113), since political parties aim to defend and persuade an audience of their own positions. And, yet, for Atkinson (2011: 131), parliamentary debates do not only attempt to persuade, but also «they lead to concrete action including [...] legislation that affects people's daily lives» and, thus, they are «highly performative». Metonymy is often regarded (Meadows, 2007; Portero Muñoz, 2011; Catalano and Waugh 2013b) as a subtle strategy to shape public opinion, which explains why it is being increasingly used in political discourse. At the same time, metonymy (and its uses with metaphor) serves the purpose of «constructing and reproducing dominant discourse» (Catalano and Waugh, 2013b: 32), leading to manipulation. Political interviews, electoral meetings and speeches, presidential addresses and pre-election debates have been widely studied (Cabrejas-Peñuelas, 2015; Cabrejas-Peñuelas and Díez-Prados, 2014; Proctor and I-Wen Su, 2011); however, to our knowledge none has attempted to make a comparative analysis of Spanish and American parliamentary debates in terms of the metonymies used. The present study attempts to fill this gap by analyzing what and how metonymies are used in the State of the Union Address (henceforth, SOTU) in the US and in the State of the Nation Address (henceforth, SONA) in Spain, which took place on January $20^{\text {th }}, 2015$ and on February $24^{\text {th }}$, 2015, respectively. Thus, we only concentrate on President Obama's and Prime Minister Rajoy's speeches. Our recent field of research (Cabrejas-Peñuelas \& Díez-Prados, 2014; Cabrejas-Peñuelas, 2015; Díez-Prados, 2016; CabrejasPeñuelas, 2018 in press) concentrates on discourse strategies (positive/negative evaluation, fallacies, metaphorical mappings) from a contrastive perspective (English-Spanish) in pre-election and parliamentary speeches that contribute to persuasion in text. The objective of the present study is to expand our previous work on metaphor (Díez-Prados, 2016; Cabrejas-Peñuelas, 2018 in press) by studying metonymy and contrast the results in the 2015 US SOTU with those found in a coetaneous address in Spanish, the 2015 sONA. The analysis of metonymies came about after newspapers commented on President Obama's use of metaphors as a rhetorical device in his 2015 sOTU to great effect, which made us wonder whether metonymies had also been used as a device for rhetorical persuasion, since the two are often found together and even interact in linguistic expressions (Benczes, 2011: 203). The following research questions will be analyzed:

(1) What metonymies do President Obama and Prime Minister Rajoy use in their American and Spanish political speeches in an attempt to convince the public of economic victory?

(2) What are the similarities and differences between the role of metonymy in shaping public opinion about economic recovery in America and Spain in both speeches? 
To answer these questions, we have chosen to analyze Obama's 2015 sOTU and Rajoy's 2015 SONA in terms of the metonymies found in the Economy section of the speeches, which is the only coinciding section across speeches. For that purpose, we take account of some of the ample bibliography on metonymy use (Meadows, 2007; Barcelona, 2011; Benczes, 2011; Shie, 2011; Catalano and Waugh, 2013b). Since both political speeches belong to two different speech traditions, we may expect similarities and differences in the use of metonymies.

Section 2 deals with soTU in the US and sonA in Spain. Section 3 offers a review of the political background of the speeches. Section 4 focuses on the use of metonymy in political discourse. Section 5 deals with the methodology used. Section 6 attempts to show the similarities and differences in metonymy use between Obama's soTU and Rajoy's sonA and, finally, section 7 provides the conclusions to the study.

\section{PARLIAMENTARY DISCOURSE: THE STATE OF THE UNION ADDRESS VS. THE STATE OF THE NATION ADDRESS. THE SOCIO-ECONOMIC CONTEXT OF THE SPEECHES}

The sotu in the US, which is delivered to Members of Congress and, only in recent decades, to the nation, is a speech in which the President reports on the current conditions of the country and establishes his programmatic priorities for the ensuing year. The President's speech is then followed by the opposing party's rebuttal, which is much shorter in length. Although there are some recurring themes in SOTU's -rhetoric about past accomplishments and future goals, bipartisanship to build consensus, and optimism to solve any problem (Shogan, 2015: 6-8)-, in the 2015 1-hour-long sOTU President Obama dealt with a variety of topics, after declaring that the financial crisis had finished and economic victory was now a reality. These included economy, natural resources, social policy, medicine, the Internet, space exploration, terrorism, cybersecurity, foreign policy, climate change, and bipartisanship.

The SONA in Spain, inspired in US SOTU's, was created by President of Congress Gregorio Peces-Barba, who defined it as a «sort of compilation or general recapitulation» (our translation) (Izquierdo Labella, 2014: 33) that happens in the years when there is no Inaugural Address. Although inspired in the US SOTU, it takes a very different format, since it was designed to be a debate. Indeed, the PM's intervention is followed by the opposing party's rebuttal and those of other political parties, which are then countered by the PM's response in a one-to-one basis or at the end of all interventions. This is then followed by the resolutions debate, in which each political party elaborates some proposals that the Congress votes for or against and which adds to the complexity of the debate. 
Rajoy's speech in the 2015 sonA lasted for 1 hour and 30 minutes and served him to congratulate himself on turning the nation around from a situation of near-bankruptcy, while the opposition lawmakers criticized his speech for being triumphalist and out of touch with reality. The PM's speech had the following main sections: economy, corruption, the Catalan independence movement, foreign policy and social policy. El País parliamentary journalist Fernando Garea indicated about SONA debates: «In most cases, governments use debates to launch powerful messages or specific proposals» (our translation) (Izquierdo Labella, 2014: 40). For that purpose, they use all means available to them to create a strong «emotional and physical reaction» (Molpeceres Arnáiz, 2012: 299) that helps them to sway public opinion in their favor. One of such means is metonymy.

The context of President Obama's sixth soTu was one of a country that was slowly coming out of recession; and had a new healthcare law, which aimed to extend insurance coverage to millions of uninsured Americans, although it was opposed by Republicans. The country had also introduced a financial regulation reform to protect consumers from abusive practices; and had created an immigration reform that facilitated legal immigration. In addition, it had nuclear talks with Iran to prevent the country from building a nuclear weapon; authorized the use of military force to fight Islamic State; and began normalizing relations with Cuba.

PM Rajoy's 2015 SONA was addressed to a country that was slowly recovering from a serious economic crisis and showed signs of improvement. It also had an independent movement in Catalonia fuelled by the region's feelings that they were contributing to Spain but they were getting back far less. In addition, the country had seen a major corruption case in the Conservative party, of which Rajoy was the leader, since PP politicians have been accused of and found guilty of creating a network of bribery, tax evasion and money laundering. Finally, it had seen the rise of new political forces -Podemos ('We can') on the left and Ciudadanos ('Citizens') on the right- that challenged the Government's tough austerity measures to emerge from the country's financial and economic meltdown.

\section{METONYMY IN THE FINANCIAL AND POLITICAL DISCOURSE}

A wealth of literature (Meadows, 2007; Gradecak-Erdeljic \& Milic, 2011) has concentrated on the study of metaphor and metonymy in political discourse and, especially, in the language of finance (Portero Muñoz, 2011; Orts Llopis \& Rea Rizzo, 2010). Metaphor and metonymy are considered «an indispensable cognitive tool for making abstract and complex concepts [...] more accessible to the general public and sometimes to the politicians themselves» (Gradečak-Erdeljić and Milic, 2011: 149). Traditionally regarded a figure of speech, metonymy is 
defined as a «cognitive process in which one conceptual entity, the vehicle [or source], provides mental access to another conceptual entity, the target, within the same domain, or I(dealized) C(ognitive) M(odel)» (Kövecses \& Radden, 1998: 39). Cognitive linguists (Lakoff \& Johnson, 1980/2003; Kövecses \& Radden, 1998) distinguish metonymy from metaphor in terms of the distinction 'directing attention versus understanding', among other criteria; that is, metonymy provides mental access to a target that is «less readily or easily available» (1980: 176), whereas metaphor serves to understand one thing in terms of another. However, for Barcelona (2011: 12) in metonymy there is an intra-domain activation of one (sub)domain by another and, thus, it is characterized by an asymmetrical mapping, in which the target is understood from the perspective of the source. This happens because «the metonymic source projects its conceptual structure onto that of the target, not by means of a systematic matching of counterparts [as in metaphor], but by conceptually foregrounding the source and by backgrounding the target» (Barcelona 2002: 226; emphasis in original).

It is precisely the notion of 'directing attention' that makes metonymy a perfect tool for politicians, who can hide less favorable elements in the target domain, while exposing others in the source domain. For example, Ferrari (2007) refers to the PART FOR WHOLE metonymy in George Bush's 2006 Address to the Nation after the $9 / 11$ bombings in the Us:

(1) Add your eyes and ears to the protection of our homeland (G.W. Bush, Address to the Nation, 2006; emphasis added).

The metonymy is used to refer to citizens who should be on the lookout to search for potential bombers and, thus, the protective role of citizens is emphasized. Bush is also appealing to the in-group ('we'), while deemphasizing the out-group ('terrorists'). This suggests that metonymy has «a key role in the development of patterns of reasoning which are created by the speaker or writer with the express purpose of shaping the thinking patterns of the listener or reader» (Littlemore, 2015: 101), leading thus to manipulation. This is especially so because metonymy is «one of the subtlest linguistic strategies that influences public opinion» (Catalano \& Waugh, 2013b: 32), as it is «processed in much the same way as literal language»(Littlemore, 2015: 103). See Ruiz de Mendoza Ibáñez \& Díez Velasco's (2002) domain reduction or target-in-source metonymy, which is used to refer to the fact that one segment of the larger domain can be reduced to fit strategically chosen characteristics. For instance, in (2) Bush uses a TARGET IN SOURCE metonymy, since he reduces the larger domain (Iraqi people) according to a set of characteristics: 
(2) The enemy in Iraq is a combination of rejectionists, Saddamists and terrorists (G. W. Bush, 30 November 2015).

The three metonymies are the following:

(1) rejectionists are those who reject the pending constitution in Iraq, (2) Saddamists are those who the Bush administration deems as supporting Saddam Hussein and, by mutually-exclusive implication, in opposition to American interests, (3) terrorists are those who incite terror (Meadows, 2007: 7; emphasis in original).

For Meadows $(2007,7)$, these metonymies «resemble racial stereotypes in that they take away human individuality and replace it with broad, impersonal group generalizations built on metonymy».

In matters of finance, metonymy is also used to camouflage the less favorable aspects of the target concept while highlighting others, according to the ideological makeup of the speaker/writer and, thus, shape public opinion as desired. Take the case of 'unemployment,' which is often the source of numerous metonymies, such as EFFECT FOR CAUSE as in «employment crisis» and «employment problems», which avoid mentioning the lack of employment (Portero Muñoz, 2011: 145). Metonymies also interact with metaphors to form complex conceptual interactions, in which metonymy functions «to develop or highlight the source or the target of a metaphor» (Catalano \& Waugh, 2013a: 408). See also «crisis», which activates the metonymies EFFECT FOR CAUSE and NATURAL/NUCLEAR DISASTER FOR FINANCIAL DISASTER («meltdown», «Storm») and the metaphors the FINANCIAL CRISIS IS A NATURAL DISASTER, UP IS GOOD and DOWN IS BAD, which mask those responsible for the crisis (Catalano \& Waugh, 2013 b). This is so because, through a process of naturalization and neutralization of language, «events related to the financial crisis appear to be 'natural' and, thus, we cannot be responsible for the terrible effects it has» (2013b: 44). Such metonymies and others have strategic governmental or corporate uses and serve as mechanisms of manipulation (as found in Portero Muñoz, 2011 and Catalano \& Waugh, 2013a, 2013b). It seems, therefore, that metonymy is an invaluable tool for mitigating responsibility and swaying public opinion to one's side.

\section{METHODOLOGY}

The 2015 SOTU in the US and in the 2015 SONA in Spain was object of analysis to find out the metonymies employed (and their interactions with metaphors) in the Economy section, which is the only coinciding topic across speeches. We were 
also interested in finding out to what extent metonymy plays a role in swaying public opinion to the politicians' side and is, thus, a tool for manipulation. For the study, we identified the metonymies used in President Obama's and Prime Minister Rajoy's speeches that served to convince the public of economic recovery after applying the Conceptual Metonymy Theory (Dirven \& Ruiz de Mendoza Ibáñez, 2010), which stems from the general framework of Conceptual Metaphor Theory (Lakoff \& Johnson, 1980/2003).

For the study of metonymies, the 2015 SOTU was taken from the American Presidency Project webpage $^{1}$ (6,718 words) and the 2015 sonA was obtained from La Moncloa webpage $^{2}$ (10,719 words), the site of the Presidency of the Spanish Government. The transcriptions were first divided into sections corresponding to the different topics; next, the Economy section in both speeches was analyzed in terms of the metonymies used (3,214 words in Obama's sOTU and 6,310 words in Rajoy's SONA; these correspond to $47.84 \%$ and $58.87 \%$, respectively of the overall speeches, which proves the importance of the Economy section). The literature on metonymies (Lakoff \& Johnson, 1980/2003; Panther \& Thornburg, 2003; Kövecses, 2010; Barcelona, 2011; Littlemore, 2015) provided insights into the concept of conceptual metonymy and the use of metonymies in politics (Meadows, 2007; Gradečak-Erdeljić \& Milić, 2011; Portero Muñoz, 2011; Catalano \& Waugh, 2013b).

For the study of metonymies, the transcripts of Obama's and Rajoy's political speeches were copied and pasted in text format to be uploaded to a freeware program called UAM corpus tool, developed by Mick O'Donnell ${ }^{3}$. This software is, in fact, a set of tools to annotate the text(s), make searches in the corpus and run descriptive and inferential statistics. For the analysis, we inserted the most common metonymies found in the political and finance arenas (Meadows, 2007; Gradečak-Erdeljić \& Milić, 2011; Portero Muñoz, 2011; Catalano \& Waugh, 2013a, 2013b). They were all conceptual metonymies (in the X FOR Y formula) (see Appendix 1).

The identification of metonymies required careful consideration, since some linguistic expressions could not be taken literally but, instead, a term functioned as «a cognitive trigger providing access to a targeted concept» (Panther \& Thornburg, 2003, 2). Following Biernacka (2013: 117), for the identification of

1. The 2015 State of the Union Address can be consulted on the American Presidency Project webpage: <http://www.presidency.ucsb.edu/sou.php>.

2. The 2015 State of the Nation Debate can be downloaded from La Moncloa webpage: <http://www.lamoncloa.gob.es/presidente/intervenciones/Documents/2015/240215DebateEs tadoNacion.pdf>.

3. The program can be downloaded for free from the web page: http://www.wagsoft.com/ CorpusTool/. 
metonymies the procedure used was that based on the Pragglejaz Group's (2007) procedure for metaphors (this metonymy analysis and identification has been adopted in influential work on metonymy; see Littlemore \& Tagg, 2016):

1. Read the entire text to get a general understanding of the overall meaning.

2. Determine lexical meanings.

3. Decide on the metonymicity of each lexical unit.

a. For each lexical unit establish its contextual meaning.

b. For each lexical unit determine if it has a more basic contemporary meaning in other contexts than the meaning in the given context.

c. If the lexical unit has a more basic contemporary meaning in other contexts than the given context, and the contextual and basic meanings are different, determine if they are connected by contiguity, causal relations and part whole relations.

4. If a connection is found in step $3 \mathrm{c}$ that is one of contiguity: check backwards and forwards to determine if any other lexical unit(s) belong(s) together semantically, thus determining the extent of the metonymy vehicle; and mark the lexical unit (or lexical units which belong together) as metonymy vehicle.

Once the words were marked as metonymical expressions, the vehicle entity (i.e. «the entity that directs attention, or provides mental access, to another entity») and the target entity (i.e. «the kind of entity to which attention, or mental access, is provided»Kövecses, 2010: 173) were distinguished. Next, a set of correspondences were laid out between the vehicle and the target entities by using the 'stand for' relationship. See example (3):

(3) This Congress still needs to pass a law that makes sure a woman is paid the same as a man for doing the same work (Obama, January 20 ${ }^{\text {th }}, 2015$ ).

«Congress» is used metonymically (INSTITUTION STANDS FOR ITS MEMBERS), since its contextual meaning (members of Congress) differs from its more basic meaning (political institution) and these meanings are closely connected, as «Congress» stands for members of Congress. Thus, the vehicle entity is «Congress» and the target entity is «members of Congress». After all the metonymical expressions had been extracted from the Economy sections of the American and Spanish speeches, the total numbers of metonymies and ratios per 1,000 words of text in the Economy section were calculated and compared.

On occasions, the analysis entailed making some methodological decisions. The first methodological decision referred to the use of the unit of analysis, the lexical unit. Step 4 of the procedure allowed for the inclusion of more than one 
lexical unit in the vehicle entity (as considered by Biernacka 2013 and Littlemore \& Tagg 2016). See example (4):

(4) We stopped the indebtedness spiral that trapped us.

It is «indebtedness spiral» (EFFECT FOR CAUSE) that carries a metonymic meaning rather than one particular word. This decision had a bearing on the ratio of metonymies per 1,000 words of text and the type/token ratios. The final methodological decision referred to the calculations of metonymies in the American and Spanish speeches for comparison. Obama and Rajoy devoted different times to dealing with economy in the speeches and, thus, the number of words also differed. This suggests that ratios per 1,000 words of text could be calculated. The differences between the ratios were calculated by using a rule of three and a subtraction:

$\mathrm{X}=$ ratio of metonymies per 1,000 words of text in the Economy section of the American speech x 100/ratio of metonymies per 1,000 words of text in the Economy section of the Spanish speech

The resulting percentage represented the ratio per 1,000 words of text in the Economy section of the American speech. The percentage of difference was then calculated by subtracting the ratio X obtained to $100 \%$ (the ratio per 1,000 words of text in the Economy section of the Spanish speech). In short form:

$\%$ of difference $=(100 \%-\mathrm{X})$

\section{RESULTS AND DISCUSSION}

In this section, we attempt to analyze Obama's and Rajoy's metonymy use in the 2015 SOTU and 2015 sONA to find out which metonymies were employed in the Economy section of the speeches to persuade the public of economic victory and to discover the similarities and differences between both politicians. For the first research question (What metonymies do President Obama and Prime Minister Rajoy use in the American and Spanish political speeches in an attempt to convince the public of economic victory?) the Economy section of both speeches was analyzed in terms of the metonymies used (see Appendix 1) as well as the 
preferred target domains. Table 1 shows that Rajoy used more overall numbers of metonymies than Obama ( $n=225$ vs. $n=148$, respectively), although both used similar range of types $(n=58$ vs. $n=62)$. The type/token ratio (total target domain types /.total number of metonymical expressions) is however higher for Obama than for Rajoy (0.39 vs. 0.28$)$ as well as the ratio per 1,000 words of text (46.04 vs. 35.68), which suggests that the American candidate used more metonymies than his Spanish counterpart in an attempt to persuade the audience of economic victory.

Table 1. Total numbers of metonymical expressions and ratios per 1,000 words of text

\begin{tabular}{|lc|lc|}
\hline \multicolumn{2}{|c|}{ OBAMA } & \multicolumn{2}{|c|}{$\boldsymbol{R A J O Y}$} \\
\hline Total metonymical expressions & 148 & Total metonymical expressions & 225 \\
Total types & 58 & Total types & 62 \\
Type/token ratio & 0.39 & Type/token ratio & 0.28 \\
Ratio per 1,000 words of text & 46.04 & Ratio per 1,000 words of text & 35.68 \\
\hline
\end{tabular}

Close examination reveals that Obama and Rajoy coincided in 12 target entities - members of the Government/governmental institutions, period of time, Americans/Spaniards, event of the speech, Members of Congress, crisis, recession, construction, cuts, jobs, bailouts,

and recovery (see Table 2). Members of the Government/governmental institutions, period of time and Americans/Spaniards are the most frequent targets in both political speeches, since these deal with the Government's actions and decisions for the countries' economic success affecting both countries. For Rajoy, recover/recovery, create/creation and crisis are also very frequent targets, given the serious effects of crisis in Spain, which were got over by economic recovery and job creation. 
Table 2. Target entities and frequency of entities in Obama's and Rajoy's speech ${ }^{4}$

\begin{tabular}{|lc|lc|}
\hline \multicolumn{1}{|c|}{ OBAMA } & & \multicolumn{2}{c|}{ RAJOY } \\
TARGET ENTITY & FREQUENCY & \multicolumn{1}{c|}{ TARGET ENTITY } & FREQUENCY \\
\hline $\begin{array}{l}\text { MEMBERS OF THE } \\
\text { GOVERNMENT/ } \\
\text { GOVERNMENTAL } \\
\text { INSTITUTIONS } \\
\text { PERIOD OF TIME }\end{array}$ & 13 & $\begin{array}{l}\text { MEMBERS OF THE } \\
\text { GOVERNMENT / } \\
\text { GOVERNMENTAL } \\
\text { INSTITUTIONS }\end{array}$ & 48 \\
AMERICANS & 13 & RECOVER/RECOVERY & 27 \\
EVENT OF THE SPEECH & 12 & CREATE/CREATION & 23 \\
PEOPLE LIVING IN THE & 11 & PERIOD OF TIME & 14 \\
UNITED STATES & 7 & CRISIS & 11 \\
MEMBERS OF CONGRESS & 6 & SPANIARDS & 10 \\
CRISIS & 5 & BAILOUT & 7 \\
ECONOMY & 5 & ACCELERATE & 6 \\
PROTECT/PROTECTIONS & 5 & EVENT OF THE SPEECH & 4 \\
RECESSION & 5 & CUTS & 3 \\
CONSTRUCTION & 3 & MEMBERS OF CONGRESS & 2 \\
CUTS & 2 & CONSTRUCTION & 1 \\
JOBS & 1 & JOBS & 1 \\
BAILOUTS & RECESSION & \\
RECOVERY & & & \\
\hline
\end{tabular}

\subsection{OBAMA'S METONYMICAL EXPRESSIONS}

Analysis of the 2015 SOTU and 2015 sONA reveals that Obama and Rajoy make much use of conceptual metonymies and their interactions with metaphor. Members of the Government/governmental institutions, period of time,Americans, event of the speech and financial crisis are the most ubiquitous targets in Obama's speech, with 10 or more instances. These serve the Democrat to persuade his

4. Due to space restrictions, only the coinciding targets and those that have a frequency of 5 or over have been included. 
audience that economic victory was a reality and, thus, gain public support for his economic policies.

\subsubsection{Members of the Government / Governmental institutions}

The Governmental institutions are referred to metonymically by mentioning the country they belong to (e.g. America) (PLACE FOR INSTITUTIONS) and the term «country», while members are substituted by the institutions they work for. Such metonymies «serve the dual function of hiding the protagonist, while at the same time endowing him with more status» (Littlemore 2015, 34). See example (5), in which Obama uses the metonymy PLACE FOR INSTITUTION within an overall strategy of positive self-presentation in an attempt to legitimatize his economic decisions. The metonymy serves him to transfer the tradition and status of America, Europe and Japan to the governmental institutions in those countries:

(5) Since 2010, America (PLACE FOR INSTITUTION) has put more people back to work than Europe, Japan, (PLACE FOR INSTITUTION) and all advanced economies (PART FOR WHOLE/ACTION FOR RESULT) combined.

Also, the metonymy is used to mask the responsibility of Congress members, who are Republican, in Obama's proposals, stressing therefore his agency:

(6) That's why I'm sending this Congress (INSTITUTION FOR MEMBERS) a bold new plan to lower the cost of community college - to zero.

The President further uses the metonymies INSTITUTION FOR MEMBERS and ACTION FOR AGENT (and their interactions with the metaphors GOVERNING IS FIGHTING and ECONOMY IS A MACHINE) within a strategy of negative otherpresentation when referring to the Republican party. This way, he sets them in a negative light for their wrong policies, since these involved undoing his major presidential accomplishments (i.e. healthcare and a financial and an immigration reform) (see (7)):

(7) We can't put the security of families at risk by taking away their health insurance, or unraveling the new rules on Wall Street (INSTITUTION FOR MEMBERS), or refighting past battles on immigration (ACTION FOR AGENT) when we've got to fix a broken system. 


\subsubsection{Period of time and event}

The words «tonight», «today», «now», «at this moment» and «9/11» are also used metonymically to refer to events happened in American history as in (8), in which «tonight» refers to the sOTU being delivered and «today» includes a period of time. 9/11 serves to illustrate negative events (i.e. the terrorist attacks happened in US soil on that date) and avoid describing the negative events. These are therefore referred to euphemistically, since in the expression «9/11» «negative evaluative factors are linguistically and psychologically so prominent and marked that people can use a part [date of the event] to refer to the whole (the whole event), and successfully convey euphemistic connotations» (Arimitsu $2015,500)$. However, the «accuracy of interpretation and understanding of this expression largely depends on the hearer's background knowledge» $(2015,490)$ :

(8) Tonight (TIME FOR EVENT), for the first time since 9/11 (TIME FOR EVENT) our combat mission in Afghanistan is over. Six years ago, nearly 180,000 American troops served in Iraq and Afghanistan. Today (POINT IN TIME FOR PERIOD OF TIME), fewer than 15,000 remain.

\subsubsection{Americans}

The metonymy PLACE FOR INHABITANTS is used with «this country» and «America» to emphasize the fact that «people are united by, or that they need to 'pull together' in times of adversity» (Littlemore 2015, 34). Thus, the metonymy has strong emotive overtones, as in example (9), in which Obama announces that the financial crisis has finished:

(9) America, for all that we have endured; for all the grit and hard work required to come back; for all the tasks that lie ahead, know this: the shadow of crisis has passed and the state of the Union is strong.

In (9), the metonymy PLACE FOR INHABITANTS also interacts with the metaphors THE CRISIS IS A CALAMITY, ECONOMY IS A JOURNEY, THE CRISIS IS BAD WEATHER and ECONOMY IS HEALTH used as tools of persuasion to frame economic success. The crisis is envisaged as a natural phenomenon that no one is responsible for and economy recovery is a journey toward victory and good health. 


\subsubsection{FINANCIAL CRISIS}

The metonymies EFFECT FOR CAUSE and NATURAL DISASTER FOR FINANCIAL CRISIS are employed to refer to the «financial crisis» (also, Catalano \& Waugh, 2013b), «recession» and «ruin», which highlight the location of the crisis and link it to the area or people that are affected, while those who hold responsibility are masked. See example (10):

(10) (Fifteen years) that saw a vicious recession spread across our nation and the world.

In the example, recession is linked to the United States and the world, while the real culprits for the accumulation of debt (banks, corporations, politicians, and so on) are not mentioned. Also, the metonymy EFFECT FOR CAUSE interacts with the metaphor THE FINANCIAL CRISIS IS A DISEASE (on occasions, with THE FINANCIAL CRISIS IS BAD WEATHER) and, thus, the crisis is natural and no one can be blamed for. This suggests that metonymy «is a very useful device when one seeks, either consciously or subconsciously, to present one's own perspective or to influence the views of others» (Littlemore, 2015: 99).

The metonymies EFFECT FOR CAUSE, ACTION FOR RESULT and POINT IN TIME FOR PERIOD are found together interacting with the metaphor ECONOMY IS A LIVING ORGANISM, which serve Obama to convince the public of the success of his policies to fight crisis. See example (11):

(11) Tonight (POINT IN TIME FOR PERIOD), after a breakthrough year for America our economy is growing (ACTION FOR RESULT) and creating jobs (ACTION FOR RESULT) at the fastest pace (EFFECT FOR CAUSE) since 1999.

In the example, economy and jobs are the result of «growing» and «creating» (and their target entities) and, thus, emphasize the wellbeing achieved after a period of economic distress. The use of «tonight» to refer to a whole time period stresses the currency of the policies undertaken.

\subsection{RAJOY'S METONYMICAL EXPRESSIONS}

Members of the Government/governmental institutions, recover/recovery, create/creation, period of time, Spaniards and financial crisis are the most common in Rajoy's speech, with 10 or more instances. These help Rajoy to convince the audience that the Spanish economy recovered from crisis without receiving a bailout. 


\subsubsection{Members of the Government / Governmental institutions}

The Governmental institutions are also metonymically referred to by mentioning «country», «nation» or «Spain» (PLACE FOR INSTITUTION) and members are replaced by the name of the institution. See example (12), in which the metonymies serve a strategy of positive self-presentation to convince the audience of Our good results. Also, the tradition associated to Spain (and the Governmental institutions and their members) is «partly transferred to the individuals themselves, and their agency is partly, but not entirely, hidden» (Littlemore, 2015: 34):

(12) El Gobierno (INSTITUTION FOR MEMBERS) ha hecho lo que tenía que hacer, pero el mérito corresponde a España y a los españoles (PLACE FOR INSTITUTION) [The Government has done what it has to do, but the merit corresponds to Spain and to Spaniards].

\subsubsection{Recover/recovery}

The metonymy ACTION FOR RESULT serves PM Rajoy the purpose of highlighting economic growth, while downplaying other less desirable effects, as in example (13). In (13) the metonymy ACTION FOR RESULT interacts with the metonymies PLACE FOR INSTITUTION and RESULT FOR ACTION and the metaphors ECONOMY IS HEALTH, SPAIN IS GOOD HEALTH/AN EXAMPLE (with linguistic realizations such as 'competitivity') and ECONOMIC CRISIS IS A DISEASE:

(13) Señorías, España (PLACE FOR INSTITUTION) inició esta recuperación (ACTION FOR RESULT) mirando al exterior, recuperando (RESULT FOR ACTION) su competitividad. [My Lords, Spain initiated this recovery looking at the outside, recovering its competitiveness]

The metonymies ACTION FOR RESULT, PLACE FOR INSTITUTION and RESULT FOR ACTION highlight the location of the recovery and link it to Spain, hiding severe budget cuts and tax increases and who was responsible for them. On occasions, metonymies mask the cuts made as "inevitable" sacrifices and, thus, the audience accepts them more willingly: «[Spaniards] aceptaron los sacrificios (SIMPLE EVENT FOR COMPLEX SUB-EVENTS/CUTS ARE SACRIFICES), aceptaron lo inevitable» [Spaniards accepted the sacrifices, accepted the inevitable]. 


\subsubsection{Create/creation}

The metonymies ACTION FOR RESULT and RESULT FOR ACTION are used to refer to job creation, which is the objective of the Government after the economic crisis (see example (14)):

(14) Hoy somos el país que más crece y el que crea (RESULT FOR ACTION) más empleo de todas las grandes economías de la zona euro. [Today, we are the country that grows the most and the one that creates the most jobs of all the great economies of the Euro zone]

In (14), it is the resultant event that is explicitly stated. The metonymy RESULT FOR ACTION interacts with the metaphors TIME FOR PERIOD OF TIME, PLACE FOR INSTITUTIONS, THE ECONOMY IS A HUMAN BEING and PART FOR WHOLE to offer a positive view of Spain after the crisis, which is then attributed to the Government's actions.

\subsubsection{Period of time}

«Today» and «at present» are used metonymically to be «deliberately vague» (Littlemore 2015, 6), as in (15):

(15) A día de hoy (POINT IN TIME FOR PERIOD OF TIME) las ventas exteriores suponen ya cerca del $33 \%$ del Producto Interior Bruto español; han aumentado (MORE IS UP) en los últimos años más que en ninguna otra economía del $G 7$ (INSTITUTION FOR MEMBERS), salvo Alemania (PLACE FOR INSTITUTION). [At present, external sales are close to $33 \%$ of the Spanish GDP; have risen in the latest years more than in any other G7 economy, except for Germany].

The metonymy POINT IN TIME FOR PERIOD OF TIME also interacts with the metaphor MORE IS UP and the metonymies INSTITUTION FOR MEMBERS and PLACE FOR INSTITUTION. These help Rajoy to persuade the audience that the Spanish economy recovered from crisis mostly due to the success of his economic policies, although the time of recovery is deliberately imprecise. Indeed, the Economy is pictured as positive, since it is mapped as a positive vertical movement and is compared to the most advanced economies in the world. The metonymy INSTITUTION FOR MEMBERS serves to deemphasize the protagonists (the Governmental institutions of the Group of 7 and their members) and the success of their policies and, thus, highlight the Spanish Government's policies. 


\subsubsection{Spaniards}

«Nation», «country», «homes» and «Spain» are used to refer to Spaniards in the metonymy PLACE FOR INHABITANTS, as in (16), which has a «strong hyperbolic feel» $(2015,33)$, since it is virtually impossible to help all Spaniards:

(16) Se trataba, pues, de sacar adelante a España entera (PLACE FOR INHABITANTS), no a fragmentos sueltos de ella [...]. [The idea was to get the whole Spain ahead, not just loose fragments of it].

In the example, Rajoy puts his metonymic slant on the information by choosing to highlight his attempt to get all Spaniards ahead (ECONOMY IS A JOURNEY metaphor), while leaving in the shade the means to do so (spending cuts and taxes rises). This way, he tries to persuade the audience to accept the economic policies introduced and he is legitimized to undertake them.

\subsubsection{Financial crisis}

The metonymies EFFECT FOR CAUSE and NATURAL DISASTER FOR FINANCIAL DISASTER (and their interactions with the metaphors THE ECONOMY IS A LIVING BODY, THE CRISIS IS A NATURAL DISASTER, THE CRISIS IS A DISEASE, to name a few) are used to make reference to the financial crisis. As in Obama's speech, these contribute to the idea that the events related to the financial crisis are "natural" and "unpredictable" and, thus, no one can be held responsible. However, no mention is made of the tough austerity measures made and the likely effects on the less fortunate citizens, despite being widespread and well-known ${ }^{5}$. This way, the measures are accepted as "necessary" consequences of crisis.

PM Rajoy also treats the financial crisis metonymically (PLACE FOR INSTITUTIONS, ACTION FOR RESULT and TIME FOR PERIOD OF TIME and their interactions with the metaphor THE CRISIS IS A CONTAINER) to distance himself from the opposing party and his wrong economic policies and, thus, highlight the negative characteristics of Them (i.e. bankruptcy), while emphasizing the positive characteristics of Us (i.e. recovery). See (17), in which Rajoy contrasts the previous and the current economic conditions in Spain and, therefore, sets himself apart from Them:

5. Numerous newspapers commented on the Partido Popular government's budget cuts on welfare, education and health and the terrible effects on the population, including shrinking family incomes and eviction ("Spain sets out $8.9 \mathrm{bn}$ euros of new austerity measures" (2011) $<$ http://www.bbc.com/news/business-16364313>). 
(17) España (PLACE FOR INSTITUTIONS) ha pasado de ser un país al borde de la quiebra a convertirse en el ejemplo de recuperación (ACTION FOR RESULT) en el que, a día de hoy (TIME FOR PERIOD OF TIME), se fijan otros países de la Unión Europea (PLACE FOR INSTITUTIONS). [Spain has passed from being a country on the brink of bankruptcy to a model of recovery that as of today provides an example to other countries of the EU].

\subsection{THE ROLE OF METONYMY IN SHAPING PUBLIC OPINION}

To answer our second research question (What are the similarities and differences between the role of metonymy in shaping public opinion about economic recovery in America and Spain in both speeches?), we compare Obama's and Rajoy's metonymical expressions in the 2015 sOTU and the 2015 SONA. An obvious similarity is the politicians' use of metonymical expressions in their speeches with an aim to convince the public of the crisis being a natural event and of the success of their economic policies to overcome crisis and, thus, gain public support for them. See the examples «the crisis worsened» and «the shadow of crisis» (EFFECT FOR CAUSE/NATURAL DISASTER FOR FINANCIAL DISASTER) and their interactions with metaphor - THE FINANCIAL CRISIS IS A DISEASE (recovery, remedying, condition, improvement, spread) and THE FINANCIAL CRISIS IS A NATURAL FORCE (indebtedness spiral, darkest months, shadow).

To fight crisis, the American and Spanish Governments implemented various economic policies that resulted in «the fastest economic growth» (ECONOMY IS A LIVING ORGANISM/EFFECT FOR CAUSE), «Our deficits $c u t »$ (GOVERNING IS HEALING/ THE GOVERNMENT IS A SURGEON/ACTION FOR RESULT) and «la recuperación del crecimiento y del empleo» [the recovery of growth and employment] (THE FINANCIAL CRISIS IS A DISEASE/ACTION FOR RESULT). And, yet, to convince the audience of the truth of economic victory, both Democrat Obama and Conservative Rajoy rely on the Us/Them relational pair, which includes using «positive characteristics attributed to self and negative characteristics attributed to the other» (Meadows, 2007: 6, emphasis in original): «the recovery is touching more and more lives», «estimular el crecimiento y acelerar el regreso a la creación de empleo» [stimulate growth and accelerate the return to employment creation] versus «voces que aconse[jan] a los ciudadanos el rechazo del esfuerzo» [voices that advice citizens rejecting efforts], «an economy where only a few of us do spectacularly well». In the examples, there is a division line between the us and them categories via the positive linguistic terms attributed to self - «recovery», «growth» and «job creation» - and the negative terms attributed to the other (the Republicans in the US and the leftish parties in Spain) - «rejecting efforts» and «only a few of us do spectacularly well». Thus, both politicians portray a positive 
picture of an economy that benefits a majority of citizens through the metonymies ACTION FOR RESULT, PART FOR WHOLE and RESULT FOR ACTION and the metaphors THE FINANCIAL CRISIS IS A DISEASE, THE ECONOMY IS A LIVING ORGANISM and THE ECONOMY IS A JOURNEY. This is not but an attempt to persuade their audience to accept their economic policies and to reject those of the opposing party.

The differences between President Obama and Prime Minister Rajoy refer to the stress given to different aspects of the economic recovery. Indeed, Rajoy stressed turning the nation around from a situation of near bankruptcy without the need of a bailout (ACTION FOR EVENT) and creating thousands of jobs (RESULT FOR ACTION). See example (18), in which Rajoy shows his attempt to protect citizens from a bailout that would have meant serious budget cuts in social policies and, thus, his unpopular economic decisions are justified:

(18) Tuvimos que soportar una batalla diaria contra quienes nos empujaban (POLITICS IS CONFLICT) para que pidiéramos el rescate (ACTION FOR EVENT). [We had to bear a daily battle against those that pushed us to request the bailout]

However, Obama asserted a bright economic picture, including a growing economy (ACTION FOR RESULT) and making policies that protect middle-class economics (RESULT FOR ACTION).

Also, in Rajoy's speech the exact measures to fight crisis are masked or substituted for neutralizing words (e.g. «inevitable sacrifices» [inevitable sacrifices]), while the responsibility of the Governing institutions remains hidden and, thus, considered not worth mentioning. This way, the politician feels justified to implement such measures and attempts to gain public support for them. The government's responsibility is however only mentioned to blame the opposing party of the ills of crisis (see (19)):

(19) logramos [...] que la actividad económica española comenzara a crecer, revirtiendo la recesión económica que heredamos del gobierno anterior (INSTITUTION FOR MEMBERS). [we succeeded in having the Spanish economic activity starting to grow, reverting the economic recession that we inherited from the previous government]

In the example, the Us/Them opposition is also used to «draw solidarity between [Rajoy (and his government)] and viewers at home and to elaborate further distance from the enemy other» (Meadows 2007, 6) (i.e. the opposing party). Similarly, in [19] «we need to set our sights higher than just making sure government doesn't halt the progress we're making» Obama shows the Republican's responsibility if the 2010 Affordable Care Act and Dodd-Frank Financial reform law are rejected. Thus, a comment that was «meant to specifically 
comment on them, unavoidably simultaneously comments on the us» (2007, 6; emphasis in original) and serves to draw solidarity with the audience and distance from the other.

\section{CONCLUSION}

Analysis of Obama's 2015 sOTU and Rajoy's 2015 sONA reveals that both politicians relied on metonymies to persuade their audiences of economic victory and, thus, used metonymies ideologically. These contribute to the positive/negative presentation of Obama and Rajoy (and their Governments)/ the opposing party in political speeches. The politicians coincided in 12 target entities -Americans/Spaniards, bailouts, construction, crisis, event of the speech, jobs, cuts, members of Congress, members of the Government/governmental institutions, period of time, recession, and recovery- and 6 of them are the most metonymically elaborated. The results for the first research question (What metonymies do President Obama and Prime Minister Rajoy use in their American and Spanish parliamentary speeches in an attempt to convince the public of economic victory?) indicate that Rajoy used more overall numbers of metonymies than Obama, both coincided in employing similar range of types, but the Democrat used a higher type/token ratio and a higher ratio per 1,000 words of text. Thus, Obama employed more metonymies than his Spanish counterpart in the same time allotted to their formulations. The results further indicate that both politicians attempted to persuade their audiences of economic success and justify their political decisions (which in Spain involved having budgets slashed and living costs risen) by portraying a picture of a country that had recovered from a serious financial crisis. For that purpose, they relied on metonymies (and their interactions with metaphors), since they are «a ubiquitous but extremely subtle means that those in power use to direct attention to or away from events or actions» (Catalano \& Waugh, 2013a: 422): a growing economy (ACTION FOR RESULT/THE ECONOMY IS A LIVING ORGANISM), deficits cut (ACTION FOR RESULT/ GOVERNING IS HEALING/THE GOVERNMENT IS A SURGEON), employment creation (ACTION FOR RESULT), and recovery (ACTION FOR RESULT/THE ECONOMIC CRISIS IS A DISEASE), to name a few.

Further analysis to answer our second research question (What are the similarities and differences between the role of metonymy in shaping public opinion about economic recovery in America and Spain in both speeches?) shows that both Democrat Obama and Conservative Rajoy portrayed the financial crisis as a natural phenomenon and, thus, replaced the discourse of crime with the discourse of a natural tragedy. This helped the audience to view the event in a non-criminal way, which contributed to mitigate or eliminate the responsibility of 
banks and financial institutions in the worldwide financial crisis. The politicians also presented a positive/negative presentation of Us and Our actions/Them and Their actions as a strategy to frame the Government's economic victory through ideologically chosen metonymies: «the recovery of growth and employment» (ACTION FOR RESULT) versus «government doesn't screw things up» (INSTITUTION FOR MEMBERS). In addition, Obama and Rajoy introduced the notion of 'protection of citizens', which for Obama involved an economic stimulus package to turn the economy around and measures addressed at the middle classes, and for Rajoy, some "inevitable" austerity measures and structural reforms. This contrasts with the wrong economic policies of the opposing party. It seems, therefore, that the role of metonymy to (re)produce the ideologies of those in power should not be underestimated but, on the contrary, it should be paid close attention to raise consciousness about its use and effects in the audience.

\section{REFERENCES}

Arimitsu, NAMI (2015): Analyzing the place for the event-type metonymies from the perspective of negative evaluative factors, Revista Brasileira de Lingüística Aplicada 15 (2): 475-502.

Atkinson, David (2011): «Political implicature in Parliamentary discourse: an analysis of Mariano Rajoy's speech on the 2006 Catalan Statute of Autonomy». In Spanish at Work: Analysing Institutional Discourse across the Spanish-speaking World, ed. Nuria Lorenzo-Dus (130-145), New York: Palgrave.

Barcelona, Antonio (2002): Clarifying and applying the notions of metaphor and metonymy within Cognitive Linguistics: an update. In RENÉ DIRVEN and RALF PÖRINGS (eds.), Metaphor and Metonymy in Comparison and Contrast (202-277), Berlín: Mouton de Gruyter.

- (2011): Reviewing the properties and prototype structure of metonymy. In Réka Benczes, Antonio Barcelona and Francisco José Ruiz de Mendoza Ibáñez (eds.), Defining Metonymy in Cognitive Linguistics: Towards a Consensus View (5-57), Amsterdam: John Benjamins.

BENCZES, RÉKA (2011): Putting the notion of "domain" back into metonymy: Evidence from compounds. In RÉKA BenCzes, ANTONIO BARCELONA and Francisco José Ruiz de Mendoza Ibáñez (eds.), Defining Metonymy in Cognitive Linguistics: Towards a Consensus View (197-215), Amsterdam: John Benjamins.

BIERNACKA, E. (2013): The role of metonymy in political discourse. Unpublished PhD thesis. Milton Keynes: The Open University. 
Cabrejas-Peñuelas, ANa B. (2015): Manipulation in Spanish and American pre-electoral debates: the Rajoy-Rubalcaba vs. the Obama-McCain debates, Intercultural Pragmatics, 13(4): 515-546.

- (2018) (in press): The language of recovery: Metaphors in Obama's and Rajoy's political speeches, Revista Española de Lingüística Aplicada (RESLA).

Cabrejas-Peñuelas, Ana B. and Mercedes Díez-Prados (2014): Positive self-evaluation versus negative other-evaluation in the political genre of preelection debates, Discourse and Society, 25(2): 159-185.

Catalano, Theresa ANd Linda R. WAugh (2013a): The ideologies behind newspaper crime reports of Latinos and Wall Street/CEOs: a critical analysis of metonymy in text and image, Critical Discourse Studies, 10(4): 406-426.

- (2013b): The language of money: How verbal and visual metonymy shapes public opinion about financial events, International Journal of Language Studies, 7 (2): 31-60.

Cortés de los Ríos, María Enriqueta (2010): Cognitive devices to communicate the economic crisis: An analysis through covers in The Economist, Ibérica, 20: 81-106.

Dirven, René and Francisco Ruiz de Mendoza Ibáñez (2010): Looking back at thirty years of Cognitive Linguistics. In Elzbieta TABaKowska, Michal Choiński and Lukasz Wirszaka (eds.), Cognitive Linguistics in Action (11-70), Berlin/ New York: Mouton de Gruyter.

Díez-Prados, Mercedes (2016): The use of metaphor and evaluation in discourse strategies in pre-electoral debates: Just about winning votes. In Manuela Romano and María Dolores Porto (eds.), Exploring Discourse Strategies in Social and Cognitive Interaction: Multimodal and Cross-Linguistic Perspectives (215-243), USA: John Benjamins.

Ferrari, Federica (2007): Metaphor at work in the analysis of political discourse: investigating a 'preventing war' persuasion strategy. Discourse and Society, 18(5): 603-625.

GradečaK-ErdelJić, Tanja and Goran Milić (2011): Metonymy at the crossroads: a case of euphemisms and dysphemisms. In RÉKA BENCZES, Antonio Barcelona and Francisco José Ruiz de Mendoza Ibáñez (eds.), Defining Metonymy in Cognitive Linguistics (147-165), Amsterdam/ Philadelphia: John Benjamins.

IzQUIERdo LABELLA, LuIS (2014): El Estado de la Nación: 30 años de la Historia de España a través de un debate, Unpublished PhD Humanities Department, Universidad Carlos III de Madrid.

Kövecses, Zoltan (2010): Metaphor: A Practical Introduction, Oxford: oup.

Kövecses, Zoltan and Günter RAdDeN (1998): Metonymy: Developing a cognitive linguistics view, Cognitive Linguistics, 9(1): 37-77. 
LAKoff, Geoff and Mark Johnson (1980/2003): Metaphors we Live by. Chicago: University of Chicago Press.

LitTlemore, JeAnetTe (2015): Metonymy: Hidden Shortcuts in Language, Thought and Communication, Cambridge: CUP.

Littlemore, Jeanette and Caroline TAgg (2016): Metonymy and text messaging: A framework for understanding creative uses of metonymy. Applied Linguistics, 1-28.

Martín Rojo, María Luisa (2000): Enfrentamiento y consenso en los debates parlamentarios sobre la política de inmigración en España, Oralia, 3: 113148.

Meadows, Bryan (2007): Distancing and showing solidarity via metaphor and metonymy in political discourse: A critical study of American statements on Iraq during the years 2004-2005, Critical Approaches to Discourse Analysis across Disciplines, 1(2): 1-17.

Molpeceres Arnáiz, SARA (2012): Imágenes mentales retórico-persuasivas en el discurso político actual: los ejemplos de Obama y Zapatero. In EMILIO del Río, María del Carmen Ruiz de la Cierva and Tomás Albadalejo (eds.), Retórica y política: Los discursos de la construcción de la sociedad (297-312), La Rioja: Ediciones Instituto de Estudios Riojanos.

Orts Llopis, María Ángeles and Camino Rea Rizzo (2011): Words for the transitional bubble: A lexical analysis of two economic crises, International Journal of English Studies, 11(1): 75-93.

Panther, Klaus-Uwe and Linda L. Thornburg (2003): Introduction: On the nature of conceptual metonymy. In KLAus-UwE PANTHER and LiNDA L. Thornburg (eds.), Metonymy and Pragmatic Inferencing (1-22), Philadelphia, PA: John Benjamins.

Portero Muñoz, Carmen (2011): Noun-noun euphemisms in the language of the global financial crisis, Journal of the Spanish Association of AngloAmerican Studies, 33(2): 137-157.

Pragglejaz Group (2007): MIP: A method for identifying metaphorically used words in discourse, Metaphor and Symbol, 22(1): 1-39.

Proctor, Katarzyna and Lily I-Wen Su (2011): The 1st person plural in political discourse - American politicians in interviews and in a debate, Journal of Pragmatics, 43: 3251-3266.

Ruiz de Mendoza Ibáñez, Francisco J. and Olga I. Díez Velasco (2002): Patterns of conceptual interaction. In René DiRven and RALF Pörings (eds.), Metaphor and Metonymy in Comparison and Contrast (489-532), Berlin: Mouton de Gruyter.

Shie, JiAn-Shiung (2011): Metaphors and metonymies in New York Times and Times Supplement news headlines, Journal of Pragmatics, 43: 1318-1334. 
Shogan, Colleen J. (2015): The President's State of the Union Address: Tradition, Function, and Policy Implications, Congressional Research Service. Retrieved from <https://www.fas.org/sgp/crs/misc/R40132.pdf>.

\section{Acknowledgements}

The present study has been funded by the research project EMO-FUNDETT: PROPER (reference code FFI2013-47792-C2-2-P), granted by the Spanish Ministry of Economy and Competitiveness.

\section{Appendix 1}

Metonymies

\begin{tabular}{|l|l|}
\hline \multicolumn{1}{|c|}{ Obama } & \multicolumn{1}{c|}{ Rajoy } \\
\hline WHOLE FOR PART & WHOLE FOR PART \\
PART FOR WHOLE & PART FOR WHOLE \\
TIME FOR THE EVENT OF THE SPEECH & TIME FOR PERIOD OF TIME \\
TIME FOR PERIOD OF TIME & TIME FOR THE EVENT OF THE SPEECH \\
PLACE FOR INSTITUTION & PLACE FOR INSTITUTION \\
INSTITUTION FOR MEMBERS & INSTITUTION FOR MEMBERS \\
PLACE FOR INHABITANTS & PLACE FOR INHABITANTS \\
ACTION FOR OBJECT INVOLVED IN THE ACTION & CONTAINER FOR CONTAINED \\
OBJECT INVOLVED IN ACTION FOR THE ACTION & A GENERAL WORD FOR A SPECIFIC WORD \\
EFFECT FOR CAUSE & ACTION FOR EVENT \\
PLACE FOR EVENT & EFFECT FOR CAUSE \\
ACTION FOR RESULT & ACTION FOR RESULT \\
ACTION FOR AGENT & RESULT FOR ACTION \\
ACTION FOR PARTICIPANT IN THE ACTION & SIMPLIFIED EVENTS FOR COMPLEX SUB- \\
ACTION FOR TARGET & EVENTS \\
ACTION FOR PATIENT & \\
ACTION FOR INSTRUMENT & \\
RESULT FOR ACTION & \\
PRODUCER FOR PRODUCT & \\
SIMPLIFIED EVENTS FOR COMPLEX SUB-EVENTS & \\
JOB FOR PERSON & \\
\hline
\end{tabular}

Note: Metonymies with tokens of two or fewer have not been included in the analysis (in italics). 